\title{
Antiviral agents in hepatitis B virus transfected cell lines: inhibitory and cytotoxic effect related to time of treatment
}

\author{
Johannes Kruining ${ }^{1}$, Rudolf A. Heijtink ${ }^{1}$ and Solko W. Schalm ${ }^{2}$ \\ ${ }^{1}$ Department of Virology, Erasmus University Rotterdam, and ${ }^{2}$ Department of Internal Medicine II, University Hospital Dijkzigt, Rotterdam, \\ The Netherlands
}

The antiviral and cytotoxic effects of ara-arabinoside monophosphate, $2^{\prime}, 3^{\prime}$, dideoxy-cytidine, ganciclovir, 9-2(-phosphonylmethoxyethyl) adenine, $2^{\prime}, 3^{\prime}$-dideoxy-3'-thiacytidine and recombinant interferon-alpha were studied using two human hepatitis B virus transfected hepatoma cell lines, HepG2 2.2.15 and HB 611. After 9 days of exposure, starting on day 3 after seeding, inhibition of extracellular HBV-DNA expressed as $\mathrm{ID}_{50}$ was in the $0.1-1.0 \mu \mathrm{M}$ range for $2^{\prime}, 3^{\prime}$ dideoxy-3'-thiacytidine and 9-2(-phosphonylmethoxyethyl) adenine and $>10 \mu \mathrm{M}$ for dideoxy-cytidine, araarabinoside monophosphate and ganciclovir in both cell lines. At $2.500 \mathrm{U} / \mathrm{ml}$ recombinant interferon-alpha showed less than $20 \%$ inhibition in both cell lines. The HBV-DNA inhibitory effects of $2^{\prime}, 3^{\prime}$-dideoxy-3' -thiacytidine and 9-2(-phosphonylmethoxyethyl) adenine were also investigated after 1 and 3 days of exposure. In that setting $\mathrm{ID}_{50}$ 's were 10 and $3.3 \mu \mathrm{M}$ for $2^{\prime}, 3^{\prime}$ dideoxy-3'-thiacytidine and $>100$ and $30 \mu M$ for 9 2(-phosphonylmethoxyethyl) adenine, respectively. No major inhibitory effect on hepatitis $B$ surface antigen and hepatitis $B$ e antigen secretion was observed for any agent in this study, except for 9-2(-phosphonylmethoxyethyl) adenine in HB 611 cells. Cytotoxicity

$\mathbf{R}$ ESEAKCH on hepatitis B virus has been hampered by the absence of an in vitro cell culture system for hepatitis B infection. Infection of hepatitis B virus in primary cultures of human hepatocytes has been reported, but great variability has been observed in levels of HBV replication (1).

As an alternative, transfection of various hepatoma cell lines with hepatitis B virus DNA has been introduced. Stable transfection was established for the

\section{Received 9 March 1994}

Correspondence: J. Kruining, Dept. of Virology, Erasmus University, P.O. Box 1738, 3000 DR Rotterdam, The Netherlands. measured by inhibition of $\left[{ }^{3} \mathrm{H}\right.$-methyl] deoxythymidine incorporation and expressed as $\mathrm{CD}_{50}$ on day 4 was in the 10-100 $\mu \mathrm{M}$ range for ara-arabinoside monophosphate; in the 100-1000 $\mu \mathrm{M}$ range for 9-2(-phosphonylmethoxyethyl) adenine, ganciclovir and dideoxy-cytidine; and $>1000 \mu \mathrm{M}$ for $2^{\prime}, 3^{\prime}$-dideoxy-3'-thiacytidine. This $\mathrm{CD}_{50}$ decreased considerably (7-100 fold) when measured on day 12 for dideoxy-cytidine, ganciclovir, 9-2(-phosphonylmethoxyethyl) adenine and $2^{\prime}, 3^{\prime}$-dideoxy-3'-thiacytidine, but was similar for ara-arabinoside monophosphate. Since the order of antiviral HBV activity and cytotoxicity of nucleoside analogues was similar in the two transfected hepatoma cell lines, we conclude that $2^{\prime}, 3^{\prime}$-dideoxy-3'-thiacytidine and 9-2(-phosphonylmethoxyethyl) adenine are very potent inhibitors of $\mathrm{HBV}$-DNA, with a longlasting effect. In view of the progressive toxicity with continuous administration, intermittent administration might be an alternative mode of therapy.

Key words: Antiviral agents; Cell culture; Cytotoxicity; Hepatitis B virus.

(C) Journal of Hepatology.

HepG2 2.2.15 and the HB 611 cell lines. Both cell lines excrete hepatitis B surface antigen, hepatitis B e antigen and complete Dane particles $(2,3)$. These two cell lines are now widely used as model systems for screening of antiviral agents with activity against HBV. In previous studies various experimental designs were described to assess the therapeutic effect of antiviral agents. Differences in time of start of exposure of cells to the agents, duration of exposure, cell system, time lapse between exposure and measurement of anti-HBV effect and different types of cytotoxicity tests may ultimately have influenced the results. Therefore, it is of interest to investigate the two commonly used HBVproducing cell lines, the HepG2 2.2.15 and the HB 611 
cells, simultaneously. For comparison of the feasibility of these cell lines, we have chosen antiviral agents with different inhibitory properties: ara-arabinoside monophosphate (Ara-AMP) (4) and ganciclovir (DHPG) as suspected DNA polymerase inhibitors (non-reactive in growth inhibition of retroviruses: J. Bazarini, personal communication); 9-2(-phosphonylmethoxyethyl) adenine (PMEA) as inhibitor of DNA polymerase as well as reverse transcriptase (5), and dideoxy-cytidine (ddC) and $2^{\prime}-3^{\prime}$-dideoxy-3'-thiacytidine (Lamivudine) as reverse transcriptase inhibitors $(6,7)$. Recombinant interferon- $\alpha$ (IFN- $\alpha$ ) is a presumed inhibitor of the viral RNA and protein synthesis $(8,9)$. It is very important to establish the effects of drug activity on cytotoxicity and the effect of cytotoxicity on the evaluation of the antiviral effect in the earliest phase of selection of new drugs. For this reason we investigated the time and duration of treatment in relation to antiviral effect and cylotoxicity.

\section{Material and Methods}

Antiviral agents

Ara-arabinoside monophosphate and $2^{\prime} 3^{\prime}$-dideoxy cytidine were purchased from Sigma Chemical Co. (St Louis, USA). Ganciclovir was purchased from Sarva Syntex Corporation (Palo Alto, USA). Recombinant interferon- $\alpha$ was a gift from the Schering Plough Corporation (Kenilworth, NY, USA). 9-2-(phosphonylmethoxyethyl) adenine was a gift from Dr. J. Balzarini (Rega Institute of the Catholic University, Leuven, Belgium). Lamivudine is the negative enantiomer of $2^{\prime}, 3^{\prime}$ dideoxy-3'-thiacytidine and was a gift from Glaxo Research and Development (Greenford, UK).

\section{Human hepatoma cell lines}

The HepG2 2.2.15 hepatoblastoma cell line was kindly donated by Dr. G. Acs (Mount Sinai Medical Center, New York, NY, USA); the HB 611 cell line was a gift from Dr. K. Matsubara (Institute of Molecular and Cellular Biology, Osaka, Japan).

Cells were seeded onto $25 \mathrm{~cm}^{2}$ tissue culture flasks (Costar) at a density of $4 \times 10^{4}$ cells $/ \mathrm{cm}^{2}$ in Dulbecco's modification of Eagle's medium (DMEM), supplemented with $2 \mathrm{mmol} / \mathrm{l}$ L-glutamine (Flow Laboratories), garamycine $(40 \mu \mathrm{g} / \mathrm{ml})$, amphotericin B $(2.5 \mu \mathrm{g}$ $\mathrm{ml})$, the neomycin analogue $\mathrm{G} 418(360 \mu \mathrm{g} / \mathrm{ml}$ for HepG2 2.2 .15 cells; $200 \mu \mathrm{g} / \mathrm{ml}$ for HB 611 cells) and $10 \%$ fetal bovine serum (FBS, Hyclone Laboratories Inc). When cells had reached confluence (day 6), FBS was reduced to $2 \%$. Cell cultures were maintained in $5 \% \mathrm{CO}_{2}$ atmosphere at $37^{\circ} \mathrm{C}$.

All antiviral agents were investigated for their antiHBV effects after continuous exposure of the cells to these drugs for 9 days. Initially, tenfold dilution steps were used. Intermediate dilution steps were chosen for the final experiments to obtain drug levels closer to the expected $50 \%$ inhibitory concentration. In these experiments exposure of the cells to the drug started on day 3 by replacing the culture medium with culture medium supplemented with the antiviral agent. This was repeated on day 6 and 9 .

In short-term exposure experiments, medium was also replaced on day 3 by culture medium containing the antiviral agent. Exposure of the cells to the drug ended after, respectively, 1 and 3 days. Medium without antiviral agent was changed on day 6 and 9 .

Cell culture supernatants from continuous ( 9 days) and short-( 1 day and 3 days)-term exposures were harvested on day 12 for HBV-DNA extraction.

\section{Analysis of $H B V-D N A$}

For analysis of extracellular HBV-DNA the cell culture supernatant was clarified by centrifugation at $1000 \mathrm{~g}$ for $10 \mathrm{~min}$. Aliquots were stored at $20^{\circ} \mathrm{C}$ until further analysis. After concentration by polyethylene glycol $(\mathrm{PEG}, 10 \% \mathrm{w} / \mathrm{v})$ precipitation, the pellets were resuspended in a buffer consisting of $10 \mathrm{mM}$ Tris- $\mathrm{HCl} \mathrm{pH}$ $8.2,400 \mathrm{mM} \mathrm{NaCl}, 2 \mathrm{mM} \mathrm{Na}{ }_{2}$ EDTA, $0.6 \mathrm{mg} / \mathrm{ml}$ proteinase $\mathrm{K}$ and $1 \%$ SDS and incubated overnight at $45^{\circ} \mathrm{C}$. Total HBV-DNA was extracted with phenol, followed by extraction with phenol:chloroform:isoamyl alcohol (25:24:1) and chloroform:isoamyl alcohol (24:1). The DNA was precipitated overnight in ethanol. After two washes with ethanol $70 \%$, the DNA pellets were dissolved in TE $(10 \mathrm{mM}$ Tris- $\mathrm{HCl} \mathrm{pH} 7.5,2$ $\mathrm{mM} \mathrm{Na} \mathrm{NDDT}_{2}$ ) in $10 \%$ of the starting volume.

For dot blot analysis, extracted DNA was applied to a Hybond $\mathrm{N}+$ membrane (Amersham Life Science Products) in the Convertible Filtration Manifold System (BRL, Life Technologies Inc.) as described previously (10). Three reference samples were included in any hybridization run for quality and sensitivity control.

Hybridization of HBV-DNA sequences was performed with a $\left.{ }^{32} \mathrm{P}\right] \mathrm{dCTP}$ labelled EcoR 1 fragment of pCP10 containing the full length $3.2 \mathrm{~kb}$ genome of HBV. All labelling reactions were carried out with the Prime-a-Gene Labelling System (Promega). HBVDNA was visualized by autoradiography. The limit of detection was $0.1 \mathrm{pg}$ HBV-DNA.

The intensity of the autoradiographic dot spots was quantitated by scanning in an LKB 222-020 Ultra Scan XL laser densitometer. The $50 \%$ inhibitory dose ( ID $_{50}$ ) was defined as the drug concentration that reduced the level of HBV-DNA in the culture medium by $50 \%$. The ID $_{50}$ values were obtained by plotting percentage inhibition compared with control (no drug) versus the drug 
TABLE 1

Inhibitory effects of antiviral agents in HepG2 2.2.15 and HB 611 cells

\begin{tabular}{|c|c|c|c|c|c|c|c|c|c|c|}
\hline \multirow{3}{*}{$\begin{array}{l}\text { Anti-viral } \\
\text { agent }\end{array}$} & \multicolumn{2}{|c|}{$\mathrm{ID}_{50}(\mu \mathrm{M})$ day 12} & \multicolumn{4}{|c|}{$\mathrm{CD}_{50}(\mu \mathrm{M})$} & \multicolumn{4}{|l|}{$\mathrm{TI}_{50}(\mu \mathrm{M})$} \\
\hline & \multirow{2}{*}{$\begin{array}{l}\mathrm{HB} 611 \\
\mathrm{~A}\end{array}$} & \multirow{2}{*}{$\begin{array}{l}\text { HepG 2.2.15 } \\
\text { B }\end{array}$} & \multicolumn{2}{|c|}{ HB 611} & \multicolumn{2}{|c|}{ HepG2 2.2.15 } & \multicolumn{2}{|l|}{ HB 611} & \multicolumn{2}{|c|}{ HepG2 2.2.15 } \\
\hline & & & $\begin{array}{l}\text { day } 4 \\
\text { C }\end{array}$ & $\begin{array}{l}\text { day } 12 \\
\text { D }\end{array}$ & $\begin{array}{l}\text { day } 4 \\
\text { E }\end{array}$ & $\begin{array}{l}\text { day } 12 \\
\text { F }\end{array}$ & $\begin{array}{l}\text { day } 4 \\
\text { C/A }\end{array}$ & $\begin{array}{l}\text { day } 12 \\
D / A\end{array}$ & $\begin{array}{l}\text { day } 4 \\
\text { E/B }\end{array}$ & $\begin{array}{l}\text { day } 12 \\
\text { F/B }\end{array}$ \\
\hline Lamivudine & 0.04 & 0.02 & 2800 & 150 & 3000 & 450 & $>1000$ & $>1000$ & $>1000$ & $>1000$ \\
\hline PMEA & 0.70 & 1.20 & 150 & 20 & 150 & 20 & 214 & 10 & 516 & 21 \\
\hline $\mathrm{ddC}$ & 10 & 50 & $>500$ & 40 & $>500$ & 4 & $>50$ & 4 & $>10$ & 0.08 \\
\hline AraAMP & 40 & 100 & 10 & 30 & 20 & 25 & 0.25 & 0.33 & 0.20 & 0.25 \\
\hline DHPG & $>100^{1}$ & $>100^{2}$ & 180 & 20 & 430 & 25 & $<1.80$ & $<0.20$ & $<4.30$ & $<0.20$ \\
\hline $\mathrm{IFN}-\alpha \mathrm{U} / \mathrm{m} 1$ & $>2500^{3}$ & $>2500^{4}$ & $>2500$ & $>2500$ & $>2500$ & $>2500$ & - & - & - & - \\
\hline
\end{tabular}

${ }^{1}$ At $100 \mu \mathrm{M} ; 44 \%$ Inhibition.

${ }^{2}$ At $100 \mu \mathrm{M} ; 20 \%$ Inhibition.

${ }^{3}$ At $2500 \mathrm{U} / \mathrm{ml} ; 10 \%$ Inhibition

${ }^{4}$ At $2500 \mathrm{U} / \mathrm{ml} ; 17 \%$ Inhibition.

concentration. The $\mathrm{ID}_{50}$ could be determined with a $15 \%$ coefficient of variation.

\section{Cytotoxicity}

The $50 \%$ cytotoxic dose $\left(\mathrm{CD}_{50}\right)$ was determined by inhibition of $\left[{ }^{3} \mathrm{H}\right.$-methyl]deoxythymidine $\left(\left[{ }^{3} \mathrm{H}\right.\right.$-methyl $]$ dThd) incorporation and measured after $24 \mathrm{~h}$ of incubation at respectively 3 and 12 days after seeding (11).

The Therapeutic Index (TI) is the ratio of $\mathrm{CD}_{50}$ over $\mathrm{ID}_{50}$.

\section{Extracellular HBsAg and $\mathrm{HBeAg}$ analysis}

$\mathrm{HBs} \mathrm{Ag}$ and $\mathrm{HBeAg}$ secretion in clarified tissue culture medium were analyzed on day 12 . $\mathrm{HBsAg}$ and $\mathrm{HBeAg}$ were determined semi-quantitatively by end-point titration in radioimmunoassays (AUSRIA II and $\mathrm{HBe}$ rDNA, Abbott Laboratories, Chicago, Ill., USA).

\section{Results}

\section{Anti-HBV effect}

The inhibitory effect on the level of HBV-DNA in tissue culture medium from HepG2 2.2.15 and HB 611 cells was determined on day 12 . The level of HBVDNA in supernatants of HB 611 cells not incubated with drugs resulted in weak signals after hybridization. Therefore Dane particle concentration by polyethyleneglycol (PEG) preceded HBV-DNA extraction and dot blot hybridization. For comparison, PEG precipitation was also applied to tissue culture medium of HepG2 2.2.15 cells.

The order of effectiveness in HepG2 2.2.15 cells, based on $50 \%$ inhibition of $\mathrm{HBV}$ replication, was: Lamivudine, PMEA, ddC, Ara-AMP, DHPG and interferon- $\alpha$. The same order was obtained for HB 611 cells (Table 1). The $50 \%$ inhibitory dose ranged from about
$0.02 \mu \mathrm{M}$ for Lamivudine to $>100 \mu \mathrm{M}$ for DHPG. For IFN- $\alpha$ only minimal inhibition was observed (10 and $17 \%$ at $2500 \mathrm{U} / \mathrm{ml}$ for HB 611 and HepG2 2.2.15, respectively).

\section{Inhibition of extra-cellular $\mathrm{HBSAg}$ and $\mathrm{HBeAg}$}

HBsAg and $\mathrm{HBeAg}$ secretion from both HepG2 2.2.15 and HB 611 cell cultures were not inhibited for the antiviral agents under study except for PMEA, which inhibited HBsAg secretion in HB 611 cell cultures. A reproducible $50 \%$ inhibition was found at $30 \mu \mathrm{M}$.

\section{Cytotoxicity}

Table 1 also shows $C_{50}$ results in the two hepatoma cell lines. On day 4 the order of $\mathrm{CD}_{50}$ was similar for HepG2 2.2.15 and HB 611, with the highest level of $\mathrm{CD}_{50}$ for Lamivudine and lowest for Ara-AMP.

Comparing day 4 with day 12 , lower levels (7-100 fold) of $C_{50}$ were observed on day 12 for Lamivudine, PMEA, ddC and DHPG, but not for Ara-AMP.

The most dramatic change was noticed for $\mathrm{ddC}$ in HepG2 2.2.15 cells. In contrast to the results on day 4, the level of $\mathrm{CD}_{50}$ on day 12 suggests that the antiviral activity on day 12 may be strongly influenced by cytotoxicity. This change steeply affected the therapeutic index of the drug (Table 1).

\section{Short treatment with PMEA and Lamivudine}

Fig. 1 illustrates that for PMEA and Lamivudine the concentration ranges of inhibitory activity and cytotoxicity are clearly separated. These two agents were studied for post-exposure inhibitory properties after short-term exposure in HepG2 2.2.15 cells. HepG2 2.2.15 cells were chosen for their favourable growth characteristics and higher virus yields compared to $\mathrm{HB}$ 


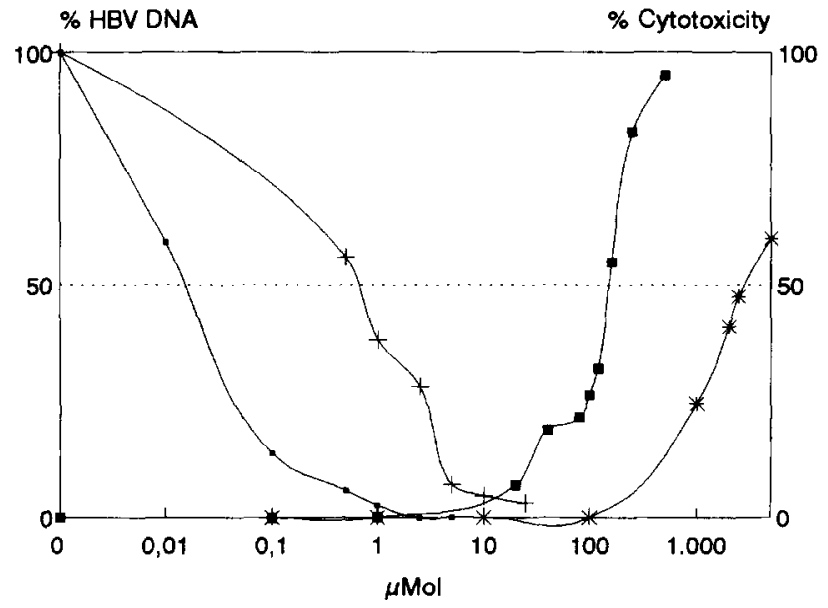

Fig. 1. Decrease of extracellular $H B V-D N A$ in HepG2 2.2 .15 cells (- Lamivudine; $+P M E A)$ and increase of cytotoxicity (- *- Lamivudine; - $P M E A$ ) with increasing concentrations of antiviral agent. $H B V-D N A$ was extracted from culture medium on day 12 after 9 days of exposure of the cells to the drug. Cytotoxicity was measured on day 4 by $\left[{ }^{3} H\right.$-methyl] dThd incorporation and measured after 24 of incubation.

611 cells. Extracellular HBV-DNA was evaluated on day 12.

After 3 days of exposure to PMEA and Lamivudine, the $\mathrm{ID}_{50}$ was $30 \mu \mathrm{M}$ and $3.3 \mu \mathrm{M}$, respectively, compared to 1.2 and $0.02 \mu \mathrm{M}$, after 9 days of exposure. In the 1-day exposure experiment PMEA and Lamivudine had $\mathrm{ID}_{50}$ 's of $>100$ and $10 \mu \mathrm{M}$, respectively.

\section{Discussion}

This is the first report on simultaneous investigation of antiviral agents in the two HBV-transfected hepatoma cell lines HepG2 2.2.15 and HB 611. The HBV inhibitory and cytotoxic effects of the agents under study were very similar for the two hepatoma cell lines after continuous exposure for 9 days. The order of effectiveness based on inhibition of extracellular HBV-DNA for both HepG2. 2.2.15 and HB 611 cell cultures was Lamivudine, PMEA, ddC, Ara-AMP, DHPG and IFN-a.

For comparison, in the literature $\mathrm{ID}_{50}$ 's for AraAMP using HepG2 2.2.15 cells were reported as $36 \mu \mathrm{M}$ for Ara-AMP (10), $0.05 \mu \mathrm{M}(12,13)$ and $0.006 \mu \mathrm{M}$ (14) for Sddc and $1.6 \mu \mathrm{M}$ (15) and $3.6 \mu \mathrm{M}$ (16) for ddC.

PMEA $(10 \mu \mathrm{M})$ inhibited HBV-DNA by $33 \%$ in HepG2 2.2.15 cells (10) and in HB 611 cells and ID $_{50}$ of $0.18 \mu \mathrm{M}$ was reported (16). IFN- $\alpha$ inhibited HBVDNA by $45 \%$ at a concentration of $10000 \mathrm{IU} / \mathrm{ml}$ in
HepG2 2.2 .15 cells (17) and by $50 \%$ at $400 \mathrm{IU} / \mathrm{ml}$ in HB 611 cells (15).

DHPG was never assayed in HepG2 2.2.15 and HB 611 cells.

In most studies on HBV inhibitory agents, cytotoxicity in cell culture systems was measured in lymphoblastoid or hepatoma cell cultures early after plating of the cells. At that time cellular DNA synthesis is expected to be highest.

Antiviral activity, measured as inhibition of the level of HBV-DNA under continuous exposure to the drug is, in fact, because of the need to change the culture medium every 3 days, determined at the end of the treatment period. Therefore, we included in our study cytotoxicity measurements on day 12 in addition to the usual measurement of cytotoxicity at the start of treatment (day 4). For both cell lines we observed an increase in cytotoxicity for Lamivudine, PMEA, ddC and DHPG after prolonged drug treatment. The increase in cytotoxicity as measured by $\left[{ }^{3} \mathrm{H}\right.$-methyl] dThd incorporation was confirmed by cell death in dye fixing experiments (results not shown).

The most dramatic change in $\mathrm{CD}_{50}$ upon time of evaluation was measured for $\mathrm{ddC}$ in HepG2 2.2.15 cells. An unfavourable cytotoxic aspect of ddC was also apparent in inhibitory measurements of mitochondrial DNA $(12,13)$. In clinical trials peripheral neuropathy was observed at all doses (18-20). Our experiments suggest that the elevated cytotoxicity of ddC on day 12 may result in an overestimation of the inhibitory effect on the level of HBV-DNA and a too favourable therapeutic index for this drug.

Reduction of HBsAg concomitant with HBV-DNA in the culture medium could not be explained by accumulation within a subcellular fraction, since with increasing drug concentration both intra-, and extracellular levels of HBV-DNA decreased quite similarly.

Compared to the other agents in our study, Lamivudine is the most vigorous antiviral agent, with low toxicity on day 4 as well as day 12 . Our in vitro findings with Lamivudine in these two cell lines were confirmed in pilot studies with Lamivudine in chronic hepatitis B patients (21). Furthermore, the outcome of our short exposure experiments are of interest for intermittent administration of antiviral drugs to reduce or avoid delayed toxic effects in man.

In summary, with the limited number of agents in this study we conclude that HepG2 2.2.15 cells are more suitable than HB 611 because of higher virus yields and better culturing characteristics, with a similar inhibitory effect on Dane particle secretion.

The high yields of HBV from the HepG2 2.2.15 cells made it possible to use a 24 -well tissue culture system 
(results not shown) and to perform direct analysis of extra-cellular HBV-DNA in cell-culture medium without PEG concentration and DNA extraction or PCR capturing (22).

Measuring cytotoxicity at the end of the incubation period may have a further discriminatory effect on the calculated and often overestimated therapeutic index. The severe toxicity observed in the FIAU study stresses once more the need for sensitive laboratory methods to predict toxic effects in man. Cell culture systems like HBV-producing hepatoma cell lines may be helpful in exploring this area.

\section{References}

1. Gripon $\mathbf{P}$, Diot C, Thézé N. Hepatitis $\mathbf{B}$ virus infection of adult human hepatocytes cultured in the presence of dimethyl sulfoxide. J Virol 1988; 62: 4136-43.

2. Sells MA, Chen ML, Acs G. Production of hepatitis B virus particles in hep $\mathrm{G} 2$ cells transfected with cloned hepatitis $B$ virus DNA. Proc Natl Acad Sci USA 1987; 84: 1005-9.

3. Tsurimoto $T$, Fujiyama A, Matsubara $\mathrm{K}$. Stable expression and replication of hepatitis $B$ virus genome in an integrated state in a human hepatoma cell line transfected with the cloned viral DNA. Proc Natl Acad Sci USA 1987; 84: 444 8.

4. Balzarini J, Mitsuya H, De Clerq E, et al. Comparative inhibitory effects of suramin and other selected compounds on the infectivity and replication of human T-cell Lymphotropic virus (HTLV-III)/lymphadenopathy-associated virus (LAV). Int J Cancer 1986; 37: 451-57.

5. Balzarini J, Holy A, Jindrich J, et al. 9-[(2RS)-3-Fluoro-2phosphonylmethoxypropyl] derivates of purines: a class of highly selective antiretroviral agents in vitro and in vivo. Proc Natl Acad Sci USA 1991; 88: 4961-65.

6. Mitsuya H, Yarchoan R, Broder RB. Molecular targets for AIDS therapy. Science 1990; 249: 1533-44.

7. Soudeyns H, Yao XJV, Gao Q, Belleau B, et al. Anti-human immunodeficiency virus type 1 activity and in vitro toxicity of 2'-deoxy-3 -thiacytidine (BCH-189), a novel heterocyclic nucleoside analog. Antimicrob Agents Chemother 1991; 35: 1386-90.

8. Hayashi Y, Koike K. Interferon inhibits hepatitis B virus replication in a stable expression system of transfected viral DNA. J Virol 1989; 63: 2936 -40.

9. Nokta MA, Reichman R, Pollard RB. Pathogenesis of viral infections. In: Galasso GJ, Whitley RJ, Merigan TC, eds.
Antiviral Agents and Viral Disease of Man, 3rd Edn. New York: Raven Press Ltd., 1990: 56.

10. Korba BE, Milman G. A cell culture assay for compounds which inhibit hepatitis B virus replication. Antiviral Res 1991; 15: 217-28.

11. Chan K, Kost DP, Michaopouos G. Multiple sequential periods of DNA synthesis and quiescence in primary hepatocyte cultures maintained on DMSO-EFG on/off protocol. J Cell Physiol 1989; 141: 584-90.

12. Chang CN, Doong SL, Zhou JH, et al. Deoxycytidine deaminase-resistant stereoisomer is the active form of $( \pm)-2^{\prime}, 3^{\prime}-$ dideoxy- $3^{\prime}$-thiacytidine in the inhibition of hepatitis $B$ virus replication. J Biol Chem 1992; 267: 13938-42.

13. Doong SL, Tsai CH, Schinazi F, Liotta DC, Cheng YC. Inhibition of the replication of hepatitis B virus in vitro by $2^{\prime}, 3^{\prime}-$ dideoxy-3'-thiacytidine and related analogues. Proc Natl Acad Sci USA 1991; 88: 8495-9.

14. Furman PA, Davis M, Liotta DC, et al. The anti-hepatitis B virus activities, cytotoxicities, and anabolic profiles of the (-) and $(+)$ enantiomers of cis-5-fluoro-1-[2-(hydroxymethylo1,3-oxathiolan-5-yl)] cytosine. Antimicrob Agents Chemother 1992; 36: 2686-92.

15. Ueda $K$, Tsurimoto $T$, Nagahata $T$, Chisaka $O$, Matsubara $\mathrm{K}$. An in vitro system for screening anti-hepatitis $\mathrm{B}$ virus drugs. Virology 1989; 169: 213-6.

16. Yokota Y, Mochizuki S, Konno K, Mori S, Shigeta S, De Clerq E. Inhibitory effects of selected antiviral compounds on human hepatitis B virus DNA synthesis. Antimicrob Agents Chemother 1991; 35: 394-7.

17. Lampertico P, Malter JS, Gerber MA. Development and application of an in vitro model for screening anti-hepatitis B virus therapeutics. Hepatology 1991; 13: 422-6.

18. Merigan TC, Skowron G, Bozette SA, et al. Circulating p24 antigen levels and responses to dideoxycytidine in human immunodeficiency virus (HIV) infections. Ann Intern Med 1989; 110: 189-94.

19. Wiltink EHH. Future prospects in antiviral therapy. Pharm Weekbl [Sci] 1992; 14: 268-74.

20. Yarchoan R, Perno CF, Thomas RV, et al. Phase I studies of $2^{\prime}, 3^{\prime}$-dideoxycytidine in severe human immunodeficiency virus infection as a single agent and alternating with zidovudine (AZT). Lancet 1988; i: 76-81.

21. Man RA de, Schalm SW, Main J, et al. A dose ranging study to determine the antiviral activity and safety of lamivudine ( $2^{\prime}$-deoxy-3'-thiacytidine) in patients with chronic hepatitis B infection. Gut 1993; 34 no. 4 (suppl): 55 (abstract).

22. Jansen RW, Johnson LC, Averett DR. High-capacity in vitro assessment of anti-hepatitis B virus compound selectivity by a virion-specific polymerase chain reaction assay. Antimicrob Agents Chemother 1993; 37: 4417. 